\title{
Totální divadlo Zdeňka Pospíšila aneb O mnohovrstevnatosti a nesamožrejmosti jednoho tvůrčího života
}

\author{
Tatjana Lazorčáková
}

Klára Hanáková. Pospa... životni a umělecká dráha rě̌iséra Zdeňka Pospišila. Brno: Janáčkova akademie múzických umění, 2021. 462 s. ISBN 978-80-7460-183-5.

Formát monografie o tvưrčí osobnosti je nevděčný, kontroverzní, poznamenaný absencí obecně platného konceptu žánru, a tudíž i věčnými pochybnostmi autorů o relevantnosti nastavené metodologie. V odborné poloze jde o žánr spojený s nedoceněnou heuristickou pracností a neustálými obavami, že ještě je co objevovat, že někde leží zapomenuty písemnosti, které mohou proměnit náhled na zkoumaného tvůrce, na jeho tvorbu a životní osudy. O to cennější je pak publikace, která se se zmíněnými nástrahami zdařile vyrovnává a dosahuje parametrů komplexní biografie postihující životní peripetie, tvưrčí vzlety i existenční zvraty osobnosti, která si nepochybně zaslouží být součástí novodobých dějin českého divadla. Za takovou lze považovat knihu teatroložky Kláry Hanákové, nazvanou familiárně Pospa... a věnovanou režisérovi Zdeňku Pospíšilovi, spojenému s počátky a formováním brněnského Divadla Husa na provázku. Publikace je aktuálním výstupem výzkumných aktivit Janáčkovy akademie múzických umění v Brně a kontinuálně navazuje na dříve zkoumané téma brněnských studiových scén (dva projekty podpořené agenturou GA ČR a vedené v letech 2009-2017 Josefem Kovalčukem), na nichž se autorka podílela (v roce 2010 vyšla její analytická studie
$\mathrm{Na}$ Pohádku máje, věnující se rekonstrukci a analýze jedné z profilových inscenací Zdeňka Pospíśila). V této souvislosti lze monografii považovat za završení dlouholetého badatelského zájmu a současně za naplnění jistého dluhu české teatrologie, protože tvorbě režiséra dosud nebyl, zřejmě i s ohledem na jeho poměrně krátkou působnost v Divadle na provázku (sedmdesátá léta) a následnou emigraci, věnována detailnější pozornost.

Úvodem autorka pečlivě sumarizuje nejen vlastní studie, zaměřené na dílčí témata režisérovy tvorby, ale také dosavadní reflexi Pospíšilovy osobnosti v textech jiných autorů, kteří většinou v rámci historického kontextu zmiňovali výběrově některé z Pospíšilových inscenací a zabývali se konkrétními znaky jeho režijní poetiky. O pečlivosti autorčina prrístupu svědčí i detailně přiblížená heuristická fáze výzkumu, která umožnila opřít rozsáhlou monografii o nově objevené prameny z osobních archivů, zejména Pospíśilovy pozůstalosti, o cenné materiály ze švýcarského exilu, o dohledané záznamy inscenací a úřední dokumenty provozní či správní povahy. Další podklady autorka získala rozhovory vedenými s pamětníky a spolupracovníky z Divadla Husa na provázku, z recenzí a z archivních zdrojů, uložených v Divadle 
Husa na provázku, Národním divadle Brno, Městském archivu Brno, Institutu umění - Divadelním ústavu, Moravském zemském muzeu, na Divadelní fakultě JAMU či v Archivu bezpečnostních složek v Kanicích.

Kniha je členěna do osmi kapitol - od chronologické sumarizace životních událostí (včetně setkání a vztahů, které formovaly režisérův vztah $\mathrm{k}$ divadlu, ale i vidění světa odrážejícího se posléze v jeho inscenacích), přes studium na JAMU, jednotlivá angažmá a nastudované inscenace, spolupráci s amatérskými i profesionálními soubory, až $\mathrm{k}$ exilovým divadelním aktivitám a návratu do vlasti s tragickým vyústěním v ředitelské pozici Hudebního divadla v Karlíně. Jak sama autorka předesílá, u každé z kapitol volila, s ohledem na archivní zdroje či informace, jiný přístup i styl. V první kapitole převládá pozitivistická důkladnost, s jakou předkládá faktografická data (od rodinného zázemí, detailů o vztazích s otcem, s kamarády či k ochotnickým aktivitám). Už tady zaujmou konkrétní informace o Pospíšilově setkávání s řadou výrazných osobností brněnského divadelního života, z nichž zejména Evžen Sokolovský byl pro Pospíšila určující. Přestože text působí jako stručný výčet chronologicky jdoucích faktů (včetně školního prospěchu, jmen sourozenců, životních partnerek a dětí, ekonomických poměrů režiséra a jeho zálib, nebo výčtu mimouměleckých exilových profesí), projevuje se v něm autorčina schopnost interpretovat údaje s vědomím širších souvislostí. Ve stejném duchu je psána i následná kapitola věnovaná studiím na JAMU, v níž autorka sleduje mimo jiné interní hodnocení Pospíšilových výkonů při přijímacím pohovoru a cituje z posudků závěrečné diplomové práce, které napsali Milan Uhde a Bořivoj Srba. Právě formulace Bořivoje Srby dokládají Pospíšilův (už tehdy) vyhraněný režijní rukopis a vypovídají o některých osobnostních rysech, ovlivňujících jeho tvơrčí dráhu (např. o neslučitelnosti jeho povahy s týmovým charakterem divadelní práce, či o nekompromisnosti a maximalismu vůči spolupracovníkům) (s. 47).

Věcný akademický styl autorka postupně opouští v důsledně strukturovaných analýzách inscenací (těch, které byly uvedené na JAMU a v prvním angažmá ve Slováckém divadle v Uherském Hradišti) a přechází ke čtenářsky vstřícnějšímu interpretačnímu stylu. Sleduje vnější i subjektivní podněty k nastudování, barvitě popisuje jednotlivé složky inscenace i jejich význam a dochází ke konfrontační komparaci ohlasů, na jejichž základě přidává vlastní závěr. V těchto částech se monografie stává fascinujícím čtením s postupně se otevírajícím příběhem o bytostném divadelníkovi a jeho cestě za totálním divadlem. Ve stejném duchu pokračuje i nejobsažnější kapitola o vrcholné tvorbě v Divadle (Husa) na provázku, kterou autorka otevírá fakty podloženou argumentací o zásadní roli Pospíšila jako zakladatele souboru (!), následně se věnuje jednotlivým inscenacím, včetně titulů uváděných v Dětském studiu, nebo agenturním inscenacím, nastudovaným pod záštitou divadla. $\mathrm{S}$ citem pro kontext propojuje $\mathrm{v}$ komentářích i časově vzdálené divadelní události, a tím se každá z analýz stává součástí systematicky budovaného svědectví nejen o osobnosti režiséra, ale také o době, o souboru i o interních vztazích členů tvưrčího týmu, o inspiračních tematických pohnutkách i kompozičních, scénických a prostorových experimentech. Potvrzuje se tak nejen Pospíšilova návaznost na éru epického divadla Mahenovy činohry, která se projevuje 
v adaptačních přístupech $\mathrm{k}$ výchozím textům, ale také jeho programové naplňování „nepravidelné dramaturgie“, termínu neodmyslitelně spojeného právě s Divadlem (Husa) na provázku a dalšími studiovými scénami sedmdesátých a osmdesátých let 20. století. Hanáková tento zavedený termín do značné míry precizuje, když uvádí, že v Pospíšilových inscenacích nešlo jen o scénické uvádění prozaických textů či poezie a adaptaci filmových scénářů, ale také o inscenování dokumentárních materiálo̊, což rozšiřuje tehdejší dramaturgickou progresivitu souboru o specifický formát doku-divadla.

Vedle faktografické kompletnosti spočívá přínos publikace především v autorčině schopnosti plasticky zachytit jednotlivé inscenace v celé šíri umělecké realizace pokud to prameny dovolí, vychází ze scénografických návrhů, světelných scénářů, režijních explikací a poznámek k realizaci, ze záznamů, z fotografií a výpovědí pamětníků, ale i z kritických reflexí a diváckého přijetí (v prrípadě inscenace $N a$ pohádku máje autorka vyhodnocuje dobovou diváckou anketu a dokládá generační složení publika či frekvenci návštěv divadla a hodnocení inscenace diváky). Nabízí také svědectví o kontinuální tvorbě režiséra pro dětské publikum, včetně jeho práce s dětskými herci v Dětském studiu Divadla (Husa) na provázku, postavené na vzájemném rozšiřování prostoru fantazie a významových přesahů, na syntetičnosti prvků zapojených do rozvíjení kreativity dětských interpretů. Navíc, konkrétní fakta o struktuře studia či o náplni výuky, která předcházela inscenačnímu procesu, vypovídají o promyšlenosti interní tvorby a provázanosti s „dospělým“ souborem. V tomto směru Hanáková představuje Pospíšila nejen jako umělce, ale také jako organizá- tora s jasnou vizí a schopností konceptualizace svých představ. Logicky je kapitola završena charakteristikou Pospíšilových režijních postupů, které autorka vřazuje do poetiky souboru v sedmdesátých letech, přičemž se nevyhýbá ani sumarizaci zmínek o problematické spolupráci s autoritativním režisérem s maximalistickými nároky a s nepředvídatelnými, mnohdy téměř nerealizovatelnými nápady.

Po kapitolách, v nichž se autorka věnuje Pospíšilově spolupráci s amatérskými soubory (pražskou Lucernou v Malostranské besedě, s pražským Divadlem Ateliér, šermířskou skupinou Duel či Divadelním studiem Josefa Skřivana) a hostujícím režiím v profesionálních divadlech (Státním divadle Brno a Divadle Vítězslava Nezvala v Karlových Varech), přichází nejobjevnější část monografie věnovaná dosud neznámé Pospísilově tvorbě v exilu. I tentokrát autorka vychází z dostupných pramenů, přičemž se mohla spolehnout především na režisérův osobní archiv a archiv jeho spolupracovnice ve Švýcarsku (herečky Catheriny Pauchard, s níž založil Théâtre au Boudufil a Théâtre Sphère), na rozhovory s některými zahraničními spolupracovníky a na výpovědi samotného režiséra. I přes jistou fragmentárnost pramenů se jí daří udržet věcnost výkladu, v němž odhaluje Pospíšilovu maximální snahu obstát v odlišných administrativních, ekonomických i uměleckých podmínkách a přibližuje jednotlivé tvưrčí projekty (včetně produkčních podmínek několika založených souborů či režijního hostování na oficiálních scénách). Shromážděné exilové recenze, vzpomínky, záznamy, ale i Pospíśilovy prostorové realizační návrhy, tak vypovídají o režisérově hektické energii a pracovitosti, ale i o názorové neústupnosti a kontroverznosti osobních reakcí, které měly v řadě případů 
podíl na krachu aktivit a existenční nejistotě. Na základě důsledného vyhodnocení pramenů představuje Hanáková jevištní podobu inscenačních projektů, jejich provozní aspekty i produkční kontext, který ovlivňoval reprízovost i kritické ohlasy. Jednotlivé exilové tituly pak dosvědčují návaznost Pospíšilovy tvorby na vrcholné „provázkovské“ období jak po stránce dramaturgické, tak výrazové. I když je tato pasáž nejpřínosnější a umožňuje poznání režisérovy komplexní tvorby, nedostatek relevantních pramenů přináší i některé pochybnosti, zvláště tam, kde se autorka může opřít spíše o subjektivně zabarvené poznámky samotného režiséra. Knihu uzavírá kapitola o dosud nezhodnoceném působení Zdeňka Pospíšila ve funkci ředitele a režiséra Hudebního divadla v Karlíně (v letech 1990-1992), z něhož chtěl vybudovat reprezentativní spektakulární scénu. Hektičnost jeho snažení sleduje autorka nejen ve výčtu uměleckých, provozních a technických změn (je obdivuhodné, jaké zásadní kroky stačil za pouhé dva roky realizovat!), ale také $\mathrm{v}$ zápase $\mathrm{s}$ kritikou a s intrikami uvnitř divadla či s tehdejšími magistrátními úředníky. Přibližuje tak na jednom konkrétním tragickém osudu uměleckou i ekonomickou nejistotu panující v divadlech v devadesátých letech. Při čtení závěrečné kapitoly jsem si uvědomila, že Pospísil byl ve svých vizích vždy o krok napřed - z Karlína chtěl vybudovat muzikálový dům evropského typu, v režijních postupech nakračoval k postmoderní stylové nespoutanosti a kontroverzností svých karlínských inscenací rozděloval kritiku na nesmiřritelné tábory.

Publikaci Kláry Hanákové můžeme považovat za zásadní příspěvek do divadelně historiografického diskursu. Pospíšilovu tvorbu kontextualizuje a představuje s analytickou hloubkou a s interpretační plastičností. Před čtenářem tak vyvstává detailní portrét nesmírně kreativní osobnosti s neústupností uměleckých, ale i provozních postojů, a také svědectví o mnohovrstevnatosti a nesamozřejmosti jednoho tvưrčího života. Za ocenění stojí také redakční pečlivost $\mathrm{v}$ prrípadě přiložených soupisů inscenací, pramenů a využité literatury, i bohatá ikonografie, která bude u pamětníků evokovat vzácné vzpomínky a pro mladší čtenáře se stane doplněním obrazu mimořádné osobnosti, podílející se na novodobých dějinách českého divadla. 